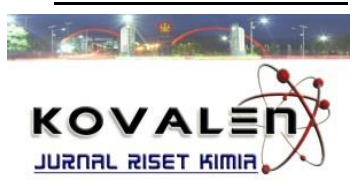

\title{
PENGARUH VARIASI JENIS ASAM TERHADAP RENDEMEN GELATIN DARI TULANG IKAN CAKALANG (Katsuwonus pelamis)
}

\section{[THE EFFECT OF VARIATION OF THE TYPE OF ACID ON GELATINE YIELD FROM CAKALANG FISH BONE (Katsuwonus pelamis)]}

\author{
Ahmad Ridhay ${ }^{1}$, Musafira ${ }^{1}$, Nurhaeni ${ }^{1}$, Nurakhirawati ${ }^{1}$, Nurul Bima Khasanah ${ }^{1}$ \\ 1) Jurusan Kimia FMIPA Universitas Tadulako, Palu \\ Diterima 11 Februari 2016, Disetujui 22 Maret 2016
}

\begin{abstract}
The research about "The Effect of Variation of the Type of Acid on Gelatine Yield from Cakalang Fish Bone (Katsuwonus pelamis)". The aim of this research was to determine the higher gelatine rendament using various of type of acid. This research used Completely Randomized Design (CRD), each treatment was done in duplo.

The acid variation in this research were Chloride, Sulphate, Phosphoric, Acetic, Oxalate and Citrate acid respectively. The result showed that the highest rendament was $14,658 \%$ at $5 \%$ of phosphoric acid. The analysis of the treatment has fulfilled the standard.
\end{abstract}

Keywords : Gelatine, Cakalang fish bone, Isolate, Yield

\begin{abstract}
ABSTRAK
Telah dilakukan penelitian tentang "Pengaruh Variasi Jenis Asam terhadap Rendemen Gelatin Dari Tulang Ikan Cakalang (Katsuwonus pelamis)". Tujuan penelitian ini adalah untuk mengetahui rendemen gelatin tertinggi terhadap variasi jenis asam. Penelitian ini dirancang menggunakan Rancangan Acak Lengkap (RAL) dan diulang 2 kali.

Penelitian tentang gelatin ini diisolasi dari tulang ikan cakalang yang telah direndam dalam variasi larutan $\mathrm{HCl}, \mathrm{H}_{2} \mathrm{SO}_{4}, \mathrm{H}_{3} \mathrm{PO}_{4}, \mathrm{CH}_{3} \mathrm{COOH}, \mathrm{H}_{2} \mathrm{C}_{2} \mathrm{O}_{4}$, dan $\mathrm{C}_{6} \mathrm{H}_{8} \mathrm{O}_{7}$ pada konsentrasi $5 \%(\mathrm{~b} / \mathrm{v})$. Hasil penelitian menunjukan bahwa pada larutan $\mathrm{H}_{3} \mathrm{PO}_{4} 5 \%$ menghasilkan rendemen tertinggi dan analisisnya telah memenuhi standar meliputi kekuatan gel, viskositas, kadar air dan kadar abu, berturut-turut nilainya yaitu $39,6 \mathrm{~mm} / \mathrm{kg} . \mathrm{s} ; 4,3784 \mathrm{cPs} ; 6,1576 \%$ dan $2,5974 \%$.
\end{abstract}

Kata Kunci : Gelatin, Tulang ikan cakalang, Isolasi, Rendemen 


\section{LATAR BELAKANG}

Ikan cakalang (Katsuwonus pelamis) adalah ikan berukuran sedang dari familia Skombride (tuna) yang bernilai komersial tinggi (Suseno, 2007). Ikan cakalang mempunyai perbandingan rata-rata untuk setiap bagian tubuh yakni : daging putih 1$2 \%$, daging merah $10 \%$, kepala $11-26 \%$, insang $3,3 \%$, isi perut $6,6 \%$, hati $0,9-3,5 \%$, ekor dan sirip 1,5-2,5\%, tulang 8,1-11,1\% dan kulit 3,8-6,6\% (Kizevetter 1993 dalam Garwan 2009). Sekitar 30\% dari tulang disusun oleh komponen-komponen organik, dan diantaranya adalah kolagen (Chi et al., 2001).

Hidrolisis kolagen dari tulang hewan dapat menghasilkan salah satu jenis protein konversi berupa gelatin (Zainuddin, 2010), yang terhidrolisis secara parsial terdiri dari campuran rantai polipeptida polidispersi dengan berat molekul lebih dari 30 kDa (Veis, 1964 dan Boran 2010 dalam Dian dkk., 2012). Reaksi yang terjadi adalah :

$$
\begin{aligned}
& \mathrm{C}_{102} \mathrm{H}_{149} \mathrm{~N}_{31} \mathrm{O}_{38}+\mathrm{H}_{2} \mathrm{O} \rightarrow \mathrm{C}_{102} \mathrm{H}_{151} \mathrm{~N}_{31} \mathrm{O}_{39} \\
& \text { Kolagen Gelatin }
\end{aligned}
$$

Penelitian tentang pembuatan gelatin yang diekstrak dari tulang ikan telah banyak dilakukan, seperti tulang ikan tuna, kakap, pari, hiu, gabus, bandeng, nila, cucut, kaci-kaci (Junianto dkk.,2006; Kusumawati dkk., 2008; Kasim, 2013; Irawan dkk., 2012; Wulandari dkk., 2013; Marzuki dkk., 2011; Maryani dkk., 2010; Astawan dan Aviana, 2003; dan Tazwir dkk., 2007).
Penelitian yang dilakukan oleh Irawan dkk., (2012) pada tulang ikan tuna menggunakan asam klorida $(\mathrm{HCl}) 5 \%$ diperoleh rendemen gelatin 19,835\%. Penelitian oleh Junianto dkk., (2006) pada tulang ikan tuna menggunakan asam klorida $(\mathrm{HCl}) \quad 5 \%$ diperoleh rendemen gelatin 9,43\%. Penelitian oleh Fatimah (2008) pada tulang ikan bandeng menggunakan asam sitrat $\left(\mathrm{C}_{6} \mathrm{H}_{8} \mathrm{O}_{7}\right) \quad 9 \%$ diperoleh rendemen gelatin 9,74\%.

Penelitian oleh Karlina (2010), pada tulang rawan ikan pari menggunakan asam klorida $(\mathrm{HCl}) 5 \%$, asam fosfat $\left(\mathrm{H}_{3} \mathrm{PO}_{4}\right) 5 \%$ dan asam asetat $\left(\mathrm{CH}_{3} \mathrm{COOH}\right) 5 \%$, diperoleh rendemen gelatin berturut-turut 13,99\%; 9,95\% dan 1,91\%.

Penelitian oleh Mulyani dkk. (2012), pada tulang ikan kakap menggunakan asam klorida $(\mathrm{HCl}) 3 \%$, asam sulfat $\left(\mathrm{H}_{2} \mathrm{SO}_{4}\right) 3 \%$ dan asam fosfat $\left(\mathrm{H}_{3} \mathrm{PO}_{4}\right) 3 \%$ diperoleh rendemen gelatin berturut-turut $\pm 14 \% ; \pm 11,5 \%$ dan $\pm 9,9 \%$. Akan tetapi penelitian tentang ekstraksi gelatin dari tulang ikan cakalang dari berbagai variasi jenis asam belum pernah dilakukan. Jika dilihat dari potensinya di Sulawesi Tengah, Ikan cakalang merupakan sumber gelatin dari perairan yang sangat melimpah keberadaannya. Sehingga memiliki potensi besar untuk dijadikan sumber gelatin halal.

\section{METODE PENELITIAN}

\section{Bahan dan Peralatan}

Bahan dasar yang digunakan dalam penelitian ini adalah tulang ikan cakalang, $\mathrm{HCl}, \mathrm{H}_{2} \mathrm{SO}_{4}, \mathrm{H}_{3} \mathrm{PO}_{4}, \mathrm{CH}_{3} \mathrm{COOH}, \mathrm{H}_{2} \mathrm{C}_{2} \mathrm{O}_{4}$, 
$\mathrm{C}_{6} \mathrm{H}_{8} \mathrm{O}_{7}$, aquadestilata, kertas $\mathrm{pH}$ universal, plastik mika, aluminium foil, karet gelang, handscoon, kertas saring whatman no.40.

Peralatan yang digunakan yaitu rotary vacuum evaporator, penetrometer, waterbath, termometer, tanur, oven, desikator, pHmeter, neraca analitik, pengaduk magnetik, pipa $U$, karet penghisap, piknometer, penyaring buchner, hot plate, cawan porselen, cawan petri, saringan, pisau, dan alat-alat gelas yang umum digunakan dalam laboratorium.

\section{Rancangan Penelitian}

Penelitian ini dirancang dengan metode Rancangan Acak Lengkap (RAL). Perlakuan yang diterapkan adalah menentukan jenis asam terbaik, yaitu $\mathrm{HCl}$, $\mathrm{H}_{2} \mathrm{SO}_{4}, \quad \mathrm{H}_{3} \mathrm{PO}_{4}, \quad \mathrm{CH}_{3} \mathrm{COOH}, \quad \mathrm{H}_{2} \mathrm{C}_{2} \mathrm{O}_{4}$, $\mathrm{C}_{6} \mathrm{H}_{8} \mathrm{O}_{7}$, dengan konsentrasi $5 \%$. Setiap perlakuan diulangi 2 kali.

Prosedur Penelitian (Junianto dkk., 2006)

\section{Isolasi Gelatin pada Variasi Jenis Asam}

Penelitian ini dilaksanakan secara bertahap yang terdiri dari 4 tahap, yaitu tahap degreasing, tahap demineralisasi, tahap ekstracting dan tahap drying.

\section{a). Tahap Degreasing}

Tulang ikan cakalang dibersihkan dari sisa-sisa daging dan lemak yang masih menempel (degreasing) yaitu dengan direndam dalam air panas suhu $\pm 90-100^{\circ} \mathrm{C}$ selama 30 menit sambil diadukaduk dan disikat (karena daging ikan cakalang yang sukar lepas). Selanjutnya tulang ditiriskan dan dipotong kecil-kecil ( $\pm 3-5 \mathrm{~cm})$ untuk memperluas permukaan.

\section{b). Tahap Demineralisasi}

Bahan baku yang telah bersih itu kemudian direndam dengan larutan asam $\left(\mathrm{HCl}, \mathrm{H}_{2} \mathrm{SO}_{4}, \mathrm{H}_{3} \mathrm{PO}_{4}, \mathrm{CH}_{3} \mathrm{COOH}, \mathrm{H}_{2} \mathrm{C}_{2} \mathrm{O}_{4}\right.$, $\mathrm{C}_{6} \mathrm{H}_{8} \mathrm{O}_{7}$, ) dengan konsentrasi $5 \%$ (perbandingan tulang dan larutan asam $=1$ : 8) dalam gelas kimia selama 48 jam sampai terbentuk ossein (tulang yang lunak). Ossein kemudian dicuci dengan menggunakan air mengalir sampai pHnya netral $(\mathrm{pH}= \pm 6-7)$.

\section{c). Tahap Ekstraksi}

Ossein yang ber-pH netral tersebut dimasukkan ke dalam beaker glass dan ditambahkan aquadest, perbandingan ossein dengan aquadest adalah $1: 6(\mathrm{~b} / \mathrm{b})$. Setelah itu diekstraksi dalam waterbath pada suhu $80^{\circ} \mathrm{C}-85^{\circ} \mathrm{C}$ selama 7 jam. Kemudian disaring dengan kertas saring whatman. Hasil saringan dipekatkan dengan rotary vacuum evaporator.

\section{d). Tahap Drying}

Cairan pekat gelatin yang diperoleh dari penguapan dengan rotary vacuum evaporator itu dituang ke dalam cawan petri yang dialasi plastik untuk dikeringkan dalam oven pada suhu $60^{\circ} \mathrm{C}$ selama 24 jam, dan didinginkan dalam desikator. Setelah kering kemudian dihaluskan dan dianalisis.

\section{Uji Kualitas Gelatin}

Penentuan Rendemen Gelatin (Marzuki, dkk., 2011)

Diperoleh dari perbandingan berat kering gelatin yang dihasilkan dengan berat 
bahan segar (tulang yang telah dicuci bersih). Besarnya rendamen (ekstrak) dapat diperoleh dengan menggunakan rumus :

Rendemen gelatin $=\frac{\text { Berat lembaran gelatin }}{\text { Berat tulang ikan cakalang }} \times 100 \%$

Penentuan Kekuatan gel (Modifikasi Zhang et al., 2011 dan Fatimah, 2008)

Larutan gelatin 6,67\% dipanaskan pada hot plate dengan suhu $40^{\circ} \mathrm{C}$ dan diaduk dengan stirer hingga mengembang, lalu suhunya dinaikkan menjadi $45^{\circ} \mathrm{C}$ selama 30 menit. Kemudian larutan gelatin dimasukan dalam gelas pengukuran dan disimpan pada suhu $10^{\circ} \mathrm{C}$ selama 18 jam. Kekuatan gel diukur menggunakan penetrometer, dihitung berat beban dan waktu pengujian penetrasi. Kekuatan gel dihitung dengan rumus :

$$
\text { Kekuatan gel }(\mathrm{mm} / \mathrm{g} \cdot \mathrm{dt})=\frac{\mathrm{a}(\mathrm{mm})}{b(\mathrm{~kg}) \times \mathrm{t}(\mathrm{dt})}
$$

Keterangan :

$\mathrm{a}=$ Hasil pengukuran

$b=$ Berat beban

$\mathrm{c}=$ waktu pengujian

Penentuan Viskositas (Modifikasi British Standard 757, 1975 dan Dogra \& Dogra, 1984)

Larutan gelatin $6,67 \%$ didispersikan dengan aquades kemudian diukur viskositasnya. Nilai viskositas dinyatakan dalam satuan centipoise (cPs). Viskositas dihitung dengan rumus :

$$
\text { Viskositas }=0.89 \times \frac{\left(\frac{\mathrm{m} 2}{\mathrm{~V} 2}\right) \times \mathrm{t2}}{\left(\frac{\mathrm{m} 1}{\mathrm{~V} 1}\right) \times \mathrm{t1}}
$$

\footnotetext{
Keterangan :

$\mathrm{m} 1=$ Berat aquadest

$\mathrm{m} 2=$ Berat larutan gelatin

V1 = Volume aquadest

$\mathrm{V} 2$ = Volume larutan gelatin

t1 = Waktu alir aquadest

t2 = Waktu alir larutan gelatin
}

Penentuan Kadar Air (AOAC, 1995)

Cawan petri dikeringkan pada suhu $105^{\circ} \mathrm{C}$ selama 1 jam, didinginkan dan ditimbang. Sebanyak $5 \mathrm{~g}$ sampel dimasukkan ke dalam cawan porselen, lalu dimasukkan ke dalam oven bersuhu $105^{\circ} \mathrm{C}$ sampai tercapai bobot konstan. Kadar air dihitung berdasarkan rumus :

$$
\text { Kadar air gelatin }(\%)=\frac{(B-A)}{\text { Berat gelatin }} \times 100 \%
$$

Keterangan :

$\mathrm{A}=\mathrm{b}$. cawan + sampel kering gelatin $(\mathrm{g})$

$\mathrm{B}=\mathrm{b}$. cawan + sampel basah gelatin $(\mathrm{g})$

\section{Penentuan Kadar Abu (AOAC, 1995)}

Cawan porselen dikeringkan pada suhu $105^{\circ} \mathrm{C}$ selama 1 jam, didinginkan dan ditimbang. Sampel yang telah diuapkan airnya dipindahkan ke cawan porselen dan dimasukkan ke dalam tanur bersuhu $600^{\circ} \mathrm{C}$. Proses penguapan dilakukan sampai semua bahan berubah warna menjadi abu-abu, kemudian sampel ditimbang. Kadar abu dihitung dengan rumus :

$$
\text { Kadar abu gelatin( } \%)=\frac{\text { Berat } \mathrm{Abu}}{\text { Berat gelatin }} \times 100 \%
$$

\section{HASIL DAN PEMBAHASAN}

Rendemen gelatin pada berbagai variasi asam dengan konsentrasi $5 \%$ terhadap tulang Ikan Cakalang

Rendemen merupakan salah satu parameter dan sifat penting dalam pembuatan gelatin. Nilai rendemen yang dihasilkan sangat menentukan efisien dan efektif tidaknya proses ekstraksi bahan baku dalam pembuatan gelatin (Fahrul, 
2005). Rendemen gelatin tersebut dihitung berdasarkan berat lembaran gelatin per berat awal tulang ikan cakalang yang telah didegreasing.

Tabel 1. Parameter rata-rata gelatin tulang ikan cakalang (berdasarkan variasi jenis asam konsentrasi 5\% dengan lama perendaman 48 jam)

\begin{tabular}{|c|c|c|c|c|c|}
\hline \multirow{2}{*}{ Jenis Asam } & \multicolumn{5}{|c|}{ Parameter } \\
\cline { 2 - 6 } & $\begin{array}{c}\text { Rende } \\
\text {-men }\end{array}$ & $\begin{array}{c}\text { Kekuatan } \\
\text { gel } \\
(\mathrm{mm} / \mathrm{kg} . \mathrm{s})\end{array}$ & $\begin{array}{c}\text { Visko- } \\
\text { sitas } \\
(\mathrm{cPs})\end{array}$ & $\begin{array}{c}\text { Kadar } \\
\text { air (\%) }\end{array}$ & $\begin{array}{c}\text { Kadar } \\
\text { abu } \\
(\%)\end{array}$ \\
\hline $\mathrm{HCl} 5 \%$ & 10,687 & 37,9 & 5,305 & 7,946 & 1,397 \\
\hline $\mathrm{H}_{2} \mathrm{SO}_{4} 5 \%$ & 8,680 & 47,3 & 1,989 & 5,808 & 2,348 \\
\hline $\mathrm{H}_{3} \mathrm{PO}_{4} 5 \%$ & 14,658 & 39,6 & 4,379 & 6,158 & 2,597 \\
\hline $\mathrm{CH}_{3} \mathrm{COOH} \%$ & 4,765 & 33,2 & 3,710 & 3,718 & 2,395 \\
\hline $\mathrm{H}_{2} \mathrm{C}_{2} \mathrm{O}_{4} 5 \%$ & 12,864 & 39,6 & 2,246 & 10,775 & 1,946 \\
\hline $\mathrm{C}_{6} \mathrm{H}_{8} \mathrm{O}_{7} 5 \%$ & 7,312 & 47,6 & 3,089 & 5,627 & 1,498 \\
\hline $\begin{array}{c}\text { Gelatin } \\
\text { pasaran }\end{array}$ & - & 45,5 & 5,438 & 6,777 & 0,979 \\
\hline
\end{tabular}

Berdasarkan tabel 1 diatas dapat dilihat bahwa rendemen tertinggi terdapat pada perendaman $\mathrm{H}_{3} \mathrm{PO}_{4} 5 \%$, sedangkan rendemen terendah dihasilkan pada perendaman $\mathrm{CH}_{3} \mathrm{COOH} 5 \%$. Hal ini diduga karena jumlah ion $\mathrm{H}^{+}$yang menghidrolisis kolagen tulang ikan cakalang berbedabeda tergantung jenis asam yang digunakan, semakin banyak ion $\mathrm{H}^{+}$ semakin meningkat jumlah rendemen. Hal ini disebabkan oleh adanya proses pengikatan mineral kalsium dalam tulang ikan cakalang sehingga menyebabkan terbebasnya kolagen dalam tulang ikan cakalang. Hal tersebut yang dapat mempermudah proses konversi kolagen menjadi gelatin (Fatimah, 2008), oleh terurainya gulungan triple helix menjadi mono helix.
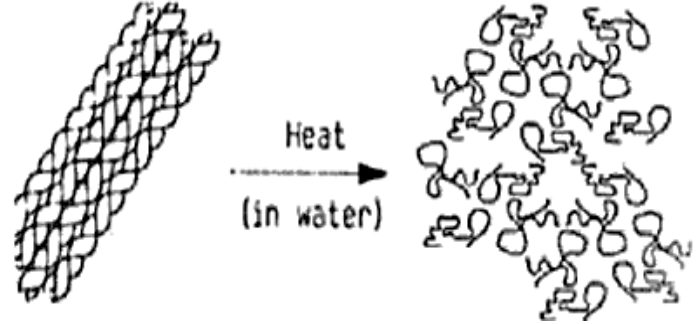

Gambar 1. Konversi kolagen menjadi gelatin (David \& Baker, 2008)

Pada penelitian yang dilakukan oleh Junianto dkk., (2006), pada tulang ikan tuna menggunakan $\mathrm{HCl} 5 \%$ (perendaman 48 jam, $\mathrm{T}=90^{\circ} \mathrm{C}, \mathrm{t}=7$ jam), nilai rendemen yang diperoleh sebesar 9,43\%. Rendemen tersebut masih lebih sedikit dibandingkan dengan rendemen penelitian ini. Meskipun cakalang dan tuna masih dalam satu famili Scombride, rendahnya rendemen yang diperoleh Junianto dkk., (2006) dikarenakan semakin banyaknya mineral dalam tulang ikan tuna yang harus diikat oleh larutan asam dibandingkan dengan tulang ikan cakalang, sehingga proses hidrolisis kolagen dalam memecah gulungan triple helix dalam tulang ikan tuna menjadi lebih sedikit.

Tabel 2. Spesifikasi Mutu Gelatin untuk Farmasi

\begin{tabular}{|c|c|c|c|c|}
\hline Parameter & $\begin{array}{c}\text { Kelas } \\
\text { Khusus }\end{array}$ & $\begin{array}{c}\text { Mutu } \\
\text { Satu }\end{array}$ & $\begin{array}{c}\text { Mutu } \\
\text { Kedua }\end{array}$ & $\begin{array}{c}\text { Mutu } \\
\text { Ketiga }\end{array}$ \\
\hline Kadar air (\%) & 14,0 & 14,0 & 14,0 & 14,0 \\
Kekuatan gel & 240 & 200 & 160 & 140 \\
(bloom) & 4,7 & 4,2 & 3,7 & 3,2 \\
Viskositas (cPs) & 1,0 & 1,0 & 2,0 & 2,0 \\
Kadar abu (\%) & $5,5-$ & $5,5-$ & $5,5-$ & $5,5-$ \\
pH & 7,0 & 7,0 & 7,0 & 7,0 \\
\hline
\end{tabular}

\section{Kualitas Gelatin}

Sifat umum dan kandungan unsurunsur mineral tertentu dalam gelatin dapat 
digunakan untuk menilai kualitas gelatin dalam standar kualitas gelatin. Sifat fisika, kimia, dan fungsional gelatin merupakan sifat yang sangat menentukan mutu gelatin (Wahyuni, 2003). Sifat yang dapat dijadikan parameter dalam menentukan kualitas gelatin antara lain adalah rendemen, kekuatan gel, viskositas, kadar air dan kadar abu.

Tabel 3. Persyaratan Kualitas/Mutu Gelatin

\begin{tabular}{|c|c|c|c|c|}
\hline \multirow{2}{*}{ Karakteristik } & \multicolumn{4}{|c|}{ Syarat } \\
\cline { 2 - 5 } Warna & $\begin{array}{c}\text { Tidak berwarna } \\
\text { sampai kuning- } \\
\text { kuningan pucat }\end{array}$ & - & c & d \\
\hline Bau, rasa & Normal & - & - & - \\
\hline Kadar air & Maks. 16\% & - & $11,45 \%$ & - \\
\hline Kadar abu & Maks. 3.25\% & - & $0,3-2 \%$ & $0,033 \%$ \\
\hline Kadar lemak & - & - & $0,25 \%$ & - \\
\hline $\begin{array}{c}\text { Kadar protein } \\
\text { total }\end{array}$ & - & - & 87,26 & 9,56 \\
\hline Kekuatan gel & - & $75-300$ bloom & $50-300 \mathrm{bloom}$ & $38,72 \mathrm{~mm} / \mathrm{g} . \mathrm{dt}$ \\
\hline Viskositas & - & $2-7,5 \mathrm{cPs}$ & $6 \mathrm{cPs}$ & - \\
\hline pH & - & $3,8-6,0$ & $3,8-5,5$ & - \\
\hline Tembaga & Maks. 30 mg/kg & - & - & - \\
\hline Seng & Maks. 100 mg/kg & - & - & - \\
\hline Sulfit & Maks. 1000 mg/kg & - & - & - \\
\hline Titik gel & - & - & $1,3^{\circ} \mathrm{C}$ & $71^{\circ} \mathrm{C}$ \\
\hline Titik leleh & - & - & $7-9$ & - \\
\hline $\begin{array}{c}\text { Titik isoelektrik } \\
\text { protein }\end{array}$ & - & - & $-30 \mathrm{C}$ & \\
\hline
\end{tabular}

a) Dewan Standarisasi Nasional (SNI), 1995

b) Tourtellote, 1980

c) GMIA, 2012

d) Fatimah, 2008

\section{Kekuatan Gel}

Berdasarkan Tabel 1 bahwa nilai kekuatan gel gelatin tertinggi adalah pada perlakuan $\mathrm{CH}_{3} \mathrm{COOH} 5 \%$, karena menghasilkan jarak paling pendek, yaitu $33.2 \mathrm{~mm} / \mathrm{kg}$.s. Hal tersebut menandakan bahwa pada perlakuan $\mathrm{CH}_{3} \mathrm{COOH} 5 \%$, jarum penusuknya menembus jarak 33.2 $\mathrm{mm}$ per satuan kg.s yang disebabkan oleh semakin kentalnya gel pada perlakuan $\mathrm{CH}_{3} \mathrm{COOH} 5 \%$. Dimana pengujian penetrasi dapat menunjukkan seberapa lama waktu penusukkan pada sampel gelatin.

Pada Tabel 1 perlakuan yang menghasilkan kekuatan gel terendah adalah pada $\mathrm{C}_{6} \mathrm{H}_{8} \mathrm{O}_{7}$ diikuti oleh $\mathrm{H}_{2} \mathrm{SO}_{4}$. Menurut Puspawati dkk., (2014), rendahnya kekuatan gel gelatin yang dihasilkan mungkin disebabkan oleh perbedaan komposisi asam amino penyusunnya dan distribusi berat molekulnya.

Kekuatan gel dalam penelitian ini jika dibandingkan dengan gelatin pasaran, 
pada $\mathrm{H}_{2} \mathrm{SO}_{4} 5 \%, \mathrm{H}_{3} \mathrm{PO}_{4} 5 \%, \mathrm{CH}_{3} \mathrm{COOH} 5 \%$ dan $\mathrm{H}_{2} \mathrm{C}_{2} \mathrm{O}_{4} 5 \%$ memiliki kekuatan gel yang lebih tinggi dari gelatin pasaran.

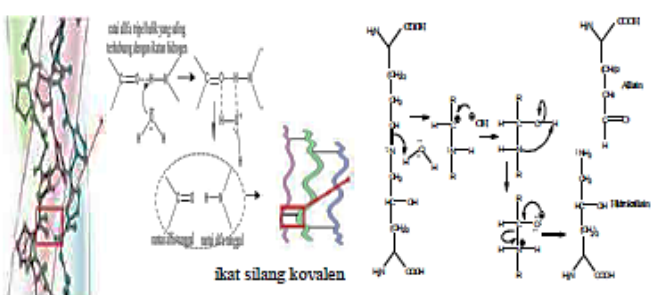

Gambar 2. Interaksi molekul air dengan ikatan hidrogen dan ikatan kovalen

\section{Viskositas}

Berdasarkan Tabel 1 nilai viskositas gelatin tulang ikan cakalang tertinggi diperoleh pada perendaman $\mathrm{HCl} 5 \%$ yaitu 5,3045 cPs dan viskositas terendah diperoleh pada perendaman $\mathrm{H}_{2} \mathrm{SO}_{4} 5 \%$ yaitu 1,9894 cPs. Perbedaan viskositas tersebut dikarenakan perbedaan kemampuan jenis asam didalam memutuskan ikatan-ikatan antar molekul. Rendahnya viskositas yang diperoleh, diakibatkan karena pendeknya rantai asam amino yang terkandung didalamnya. Hal ini didukung oleh Chamidah dan Elita (2002), lemahnya ikatan silang akan menyebabkan kolagen mudah terhidrolisis, hidrolisis ini dapat menurunkan berat molekul gelatin yang akan menurunkan viskositas larutan gelatin.

Viskositas dalam penelitian ini jika dibandingkan dengan standar bahan untuk farmasi (Peranginangin dkk., 2005), gelatin tipe A (Toutellote, 1980), GMIA (2001), hanya ada $\mathrm{CH}_{3} \mathrm{COOH} 5 \%$ dan $\mathrm{H}_{3} \mathrm{PO}_{4} 5 \%$ yang sesuai standar.

\section{Kadar Air}

Berdasarkan Tabel 1 nilai kadar air tertinggi terdapat pada gelatin dengan perendaman asam oksalat $5 \%$ yakni $10,78 \%$ dan nilai kadar air terendah terdapat pada gelatin perendaman asam asetat $5 \%$ yakni $3,72 \%$. Perbedaan nilai kadar air gelatin tersebut dipengaruhi oleh perbedaan kemampuan jenis asam dalam mengisolasi kolagen tulang ikan cakalang menjadi gelatin.

Kadar air dalam gelatin tulang ikan cakalang dalam penelitian ini pada variasi asam telah memenuhi standar yang diperkenankan oleh Standar Nasional Indonesia (SNI) No. 3735 tahun 1995 untuk produk gelatin yaitu maksimum 16\%, maupun GMIA maksimum 11,45\% dan standar gelatin untuk bahan farmasi (14\%).

\section{Kadar Abu}

Berdasarkan Tabel 1 bahwa nilai kadar abu tertinggi terdapat pada gelatin perendaman $\mathrm{H}_{3} \mathrm{PO}_{4} 5 \%$ dan nilai kadar abu terendah terdapat pada gelatin perendaman $\mathrm{HCl} 5 \%$. Hal ini menunjukkan bahwa pada $\mathrm{H}_{3} \mathrm{PO}_{4} \quad 5 \%$ proses demineralisasi berlangsung maksimal, karena mampu mendegradasi mineral dalam tulang ikan cakalang paling banyak. Sehingga semakin banyak ikatan peptida dalam kolagen terpotong, menyebabkan semakin besar mineral yang menempel pada ossein dan terlarut di dalam larutan gelatin. Menurut Courts \& Johns (1977), pembuatan gelatin secara proses asam dapat mengekstrak komponen non kolagen 
dan komponen tersebut terbawa dalam larutan.

Berdasarkan penelitian yang telah dilakukan oleh Junianto dkk., (2006) pada tulang ikan tuna dengan perendaman $\mathrm{HCl}$ $5 \%$ diperoleh kadar abu sebesar 1,9\%. Nilai tersebut masih lebih tinggi jika dibandingkan dengan penelitian ini pada larutan $\mathrm{HCl} 5 \%$ dan $\mathrm{C}_{6} \mathrm{H}_{8} \mathrm{O}_{7} 5 \%$, namun masih lebih rendah jika dibandingkan dengan larutan $\mathrm{H}_{2} \mathrm{SO}_{4} 5 \%, \mathrm{H}_{3} \mathrm{PO}_{4} 5 \%$, $\mathrm{CH}_{3} \mathrm{COOH} 5 \%$ dan $\mathrm{H}_{2} \mathrm{C}_{2} \mathrm{O}_{4} 5 \%$.

Kadar abu pada penelitian ini jika dibandingkan dengan nilai kadar abu gelatin dari Dewan Standarisasi Nasional (1995) dan gelatin standar GMIA (2012), hanya ada $\mathrm{HCl} 5 \%, \mathrm{H}_{2} \mathrm{C}_{2} \mathrm{O}_{4} 5 \%, \mathrm{C}_{6} \mathrm{H}_{8} \mathrm{O}_{7}$ $5 \%$, dan $\mathrm{H}_{3} \mathrm{PO}_{4} 5 \%$ yang sesuai standar.

\section{KESIMPULAN}

Berdasarkan penelitian yang telah dilakukan, dapat disimpulkan bahwa jenis asam yang dapat menghasilkan rendemen gelatin tulang ikan cakalang tertinggi adalah $\mathrm{H}_{3} \mathrm{PO}_{4} \quad 5 \%$ sebesar $14,66 \%$. Larutan $\mathrm{H}_{3} \mathrm{PO}_{4} 5 \%$ juga telah memenuhi standar meliputi rerata nilai kekuatan gel 39,6 mm/kg.s; viskositas 4,38 cPs; kadar air $6,16 \%$ dan kadar abu 2,60\%.

Perlu dilakukan analisis asam amino untuk mengetahui komposisi asam amino, analisis logam berat dan kandungan mikrobiologi dari gelatin tulang ikan cakalang.

\section{UCAPAN TERIMAKASIH}

Ucapan terimakasih peneliti haturkan kepada DP2M Dikti yang telah membiayai penelitian ini dan kepada laboran Jurusan Kimia FMIPA UNTAD.

\section{DAFTAR PUSTAKA}

Astawan M., Aviana T. 2003. Pengaruh Jenis Larutan Perendaman serta Metode Pengeringan terhadap Sifat Fisik, Kimia, dan Fungsional Gelatin dari Kulit Cucut. Jurnal Teknologi dan Industri Pangan. 14 (1): 7-13.

AOAC (the Association of Official Analytical Chemist). 1995. Official Methods of Analysis. Inc, Washington, DC. Chap. $38: 1-3$.

British Standard 757. 1975. Sampling and Testing of Gelatin. In : Imeson. 1992. Thickening and Gelling Agents. New York: Academis Press.

Chamidah A., Elita C. 2002. Pengaruh Proses Pengolahan terhadap Kualitas Gelatin Kulit Ikan Hiu. Prosiding Seminar Nasional PATPI. Malang, 30-31 Juli 2002.

Chi H.L., Anuj S., Yungyung I. 2001. Review Biomedical Application of Collagen. International Journal of Pharmaceutics.

Courts A., Johns P. 1977. Uses of collagen in edible products. In: Ward, AG. dan Courts, A. (eds.). The Science and Technology of Gelatin. Academic Press, New York.

David W.V.E., Baker MT. 2008. The Chemistry Animal Glue System (www.amstelproducts. nl/.../chemistry. $h t m)$. Diakses pada tanggal 14 Maret 2015.

Dewan Standarisasi Nasional. 1995. SNI 06-3735-1995. Mutu dan Cara Uji Gelatin. Jakarta: Dewan Standarisasi Nasional.

Dian PP., Darmawan E., Tjahyono. 2012. Isolasi dan Sintesis Gelatin Sisik Ikan 
Kakap Putih (Lates carcarifer) Berikatan Silang dengan Teknik Industri Irradiasi Gamma. Jurnal Sains Materi Indonesia, 14 (1) : 4046.

Dogra S.K., Dogra S. 1984. Physical Chemistry Through Problems. Eiley Eastern Limited.

Fahrul. 2005. Kajian Ekstraksi Gelatin dari Kulit Ikan Tuna (Thunnus alalunga) dan Karakteristiknya sebagai Bahan Baku Industri Farmasi. [Tesis]. Bogor: Institut Pertanian Bogor.

Fatimah D. 2008. Efektivitas Penggunaan Asam Sitrat dalam Pembuatan Gelatin Tulang Ikan Bandeng (Chanos-Chanos furskal). [Skripsi]. Malang: Jurusan Kimia, Fakultas Sains dan Teknologi, Universitas Islam Negeri Malang.

Garwan R. 2009. Perkembangan histamin selama proses fermentasi penyimpanan produk bekasang jeroan ikan cakalang (Katsuwonus pelamis). Skripsi Bogor. Fakultas IImu Perikanan dan Kelautan, Institut Pertanian Bogor.

GMIA. 2012. Gelatin Handbook. Gelatin Manufacturers Institute of America.

Irawan D.M., Kristiana I., Aditia MAS. 2012. Studi Perbandingan Kualitas Gelatin dari Limbah Kulit Ikan Tuna (Thunnus spp.), Kulit Ikan Pari (Dasyatis sp.) dan Tulang Ikan Hiu (Carcarias sp.) sebagai Alternatif Penyedia Gelatin Halal. Laporan PKMP. Malang: Teknologi Hasil Perikanan, Fakultas Perikanan. Universitas Brawijaya.

Junianto K., Haetami, Ine M. 2006. Produksi Gelatin dari Tulang Ikan dan Pemanfaatannya sebagai Bahan Dasar Pembuatan Cangkang Kapsul. Laporan Penelitian Hibah Bersaing tahun I. Fakultas Perikanan dan IImu Kelautan. Universitas Padjajaran.

Karlina IR., Atmaja L. 2010. Ekstrak Gelatin dari Tulang Rawan Ikan Pari
(Himantura gerrardi) pada Variasi Larutan Asam untuk Perendaman. Prosiding Skripsi Semester Gasal 2009/2010. Surabaya: Jurusan Kimia, Fakultas Matematika dan IImu Pengetahuan Alam. Institut Teknologi Sepuluh November.

Kasim S. 2013. Pengaruh Variasi Jenis Pelarut Asam pada Ekstraksi Kolagen dari Ikan Pari (Himantura gerrardi) dan Ikan Tuna (Thunnus sp). Majalah Farmasi dan Farmakologi. 17 (2) : 35-38.

Kusumawati R., Tazwir, Mawasto A. 2008. Pengaruh Perendaman dalam Asam Klorida terhadap Kualitas Gelatin Tulang Ikan Kakap Merah (Lutjanus sp). Jurnal Pascapanen dan Bioteknologi Kelautan dan Perikanan, 3 (1).

Maryani T., Surti, Ibrahim R. 2010. Aplikasi Gelatin Tulang Ikan Nila Merah (Oreochromis niloticus) terhadap Mutu Permen Jelly. Jurnal Saintek Perikanan. 6 (1) : 62-70.

Marzuki A., Pakki E., Zulfikar F. 2011. Ekstraksi dan Penggunaan Gelatin dari Limbah Tulang Ikan Bandeng (Chanos chanos Forskal) sebagai Emulgator dalam Formulasi Sediaan Emulsi. Majalah Farmasi dan Farmakolog. 15 (2) : 63-68.

Mulyani T., Sudaryati, Rahmawati SF. 2012. Hidrolisis Gelatin Tulang Ikan Kakap menggunakan Larutan Asam. Program Studi Teknologi Pangan, FTI UPN "Veteran" Jatim. Surabaya (http://ejournal.upnjatim.ac.id/index.p hp/rekapangan/article/view/406).

Diakses pada tanggal 17 april 2015.

Peranginangin, R., A.S. Mulyasari dan Tazwir. 2005. Karakterisasi Mutu Gelatin yang diproduksi dari Tulang Ikan Patin (Pangsius hypopthalmus) Secara Ekstraksi Asam. Jurnal Penelitian Perikanan Indonesia (http://isjd.pdii.lipi.go.id/index.php/sea rch.html?act=tampil\&id=47247\&idc=3 
3). Diakses pada tanggal 17 april 2015.

Puspawati NM., Simpen IN., Suciptawati NLP. 2014. Karakteristik Sifat Fisiko Kimia Gelatin Halal yang Diekstrak dari Kulit Ayam Boiler melalui Variasi Suhu. [Skripsi]. Udayana: Jurusan Kimia, Fakultas MIPA Universitas Udayana.

Suseno. 2007. Menuju Perikanan Berkelanjutan. Jakarta: Cidesindo.

Tazwir D.L., Ayudianti, Peranginangin R. 2007. Optimasi Pembuatan Gelatin dari Tulang Ikan Kaci-Kaci (Plectorhynchus chaetodonoides lac.) Menggunakan Berbagai Konsentrasi Asam dan Waktu Ekstraksi. Jurnal Balai Besar Riset Pengolahan Produk dan Bioteknologi Kelautan dan Perikanan. 2(1): 35-43.

Tourtellotte, P. 1980. Gelatin di dalam Encyclopedia of Science and Technology. NewYork: McGraw-Hill Book Co.

Wahyuni M., Rosmawati. 2003. Perbaikan Daya Saing Industri Pengolahan Perikanan Melalui Pemanfaatan Limbah Non Ekonomis Ikan Menjadi Gelatin. Departemen Kelautan dan Perikanan Republik Indonesia (http://www.dkp.go.id). Diakses pada tanggal 14 Maret 2015.

Wulandari A., Supriadi, Purwanto B. 2013. Pengaruh Defatting dan Suhu Ekstraksi terhadap Karakteristik Fisik Gelatin Tulang Ikan Gabus (Channa striata). Fishtech. 2(1): 31-45.

Zainuddin I. 2010. Pembuatan Gelatin Lembaran (Leaves Gelatine) dari Kulit Ikan. Laporan Akhir Program Insentif Percepatan Difusi Dan Pemanfaatan Iptek. Jakarta Pusat : Bidang Fokus Ketahanan Pangan. Deputi Bidang Teknologi Agroindustri Dan Bioteknologi Badan Pengkajian Dan Penerapan Teknologi.

Zhang, Shiying Xu, Zhang Wang. 2011. Pre-treatment optimization and properties of gelatin from freshwater fish scales. J. Food and Bioproducts Processing. 89(3): 185-193. 